\title{
Environmental setting of deep-water oysters in the Bay of Biscay
}

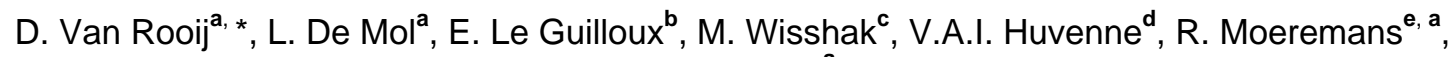 \\ J.-P. Henriet ${ }^{a}$
}

\footnotetext{
${ }^{a}$ Renard Centre of Marine Geology, Ghent University, Krijgslaan 281 S8, B-9000 Gent, Belgium

${ }^{b}$ IFREMER, Laboratoire Environnement Profond, BP70, F-29280 Plouzané, France

${ }^{\mathrm{c}}$ GeoZentrum Nordbayern, Erlangen University, Loewenichstr. 28, D-91054 Erlangen, Germany

${ }^{\mathrm{d}}$ Geology and Geophysics Group, National Oceanography Centre, European Way, SO14 3 ZH Southampton, UK

e Scripps Institution of Oceanography, UCSD, La Jolla, CA, United States of America
}

\author{
*: Corresponding author : David Van Rooij, Tel.: +32 92644583 ; fax: +32 92644967 ; \\ email address : david.vanrooij@ugent.be
}

\begin{abstract}
:
We report the northernmost and deepest known occurrence of deep-water pycnodontine oysters, based on two surveys along the French Atlantic continental margin to the La Chapelle continental slope (2006) and the Guilvinec Canyon (2008). The combined use of multibeam bathymetry, seismic profiling, CTD casts and a remotely operated vehicle (ROV) made it possible to describe the physical habitat and to assess the oceanographic control for the recently described species Neopycnodonte zibrowii. These oysters have been observed in vivo in depths from 540 to $846 \mathrm{~m}$, colonizing overhanging banks or escarpments protruding from steep canyon flanks. Especially in the Bay of Biscay, such physical habitats may only be observed within canyons, where they are created by both long-term turbiditic and contouritic processes. Frequent observations of sand ripples on the seabed indicate the presence of a steady, but enhanced bottom current of about $40 \mathrm{~cm} / \mathrm{s}$. The occurrence of oysters also coincides with the interface between the Eastern North Atlantic Water and the Mediterranean Outflow Water. A combination of this water mass mixing, internal tide generation and a strong primary surface productivity may generate an enhanced nutrient flux, which is funnelled through the canyon. When the ideal environmental conditions are met, up to 100 individuals per $\mathrm{m}^{2}$ may be observed. These deep-water oysters require a vertical habitat, which is often incompatible with the requirements of other sessile organisms, and are only sparsely distributed along the continental margins. The discovery of these giant oyster banks illustrates the rich biodiversity of deep-sea canyons and their underestimation as true ecosystem hotspots.
\end{abstract}

\section{Research Highlights}

Neopycnodonte zibrowii oysters occur in a bathymetric range between 350 and $846 \mathrm{~m}$. $>N$. zibrowii habitat requires steep slopes with overhanging banks and escarpments. This underestimated deepwater community occurs almost exclusively in canyons. Suitable habitats created by interplay between turbiditic and contouritic processes.

Keywords : Bay of Biscay ; Deep-water oysters ; Canyons ; Habitat ; Resuspension ; MOW ; Neopycnodonte zibrowii 


\section{Introduction}

Ocean margins are dynamic environments which host valuable deep-water benthic ecosystems. Along the Eastern Atlantic margin from Morocco to Norway, several „deep-water ecosystem hotspots' have been identified in association with a complex interplay of oceanography, geology, seabed morphology, sediment and nutrient supply (Weaver and Gunn, 2009). Cold-water coral reefs and canyon environments are receiving particularly close attention (Arzola et al., 2008; Canals et al., 2006; De Mol et al., accepted; de Stigter et al., 2007; Dorschel et al., 2009; Mienis et al., 2007; Palanques et al., 2009; Wienberg et al., 2009). Cold-water coral occurrences have been identified over virtually the entire European margin and their reefs feature a high biodiversity (Freiwald et al., 2004; Reveillaud et al., 2008; Roberts et al., 2006). They belong to the Earth's most precious and endangered ecosystems, threatened by fisheries and ocean acidification (Freiwald et al., 2004; Halpern et al., 2008; IPCC, 2007; Roberts et al., 2006). The main driver for this ecosystem is a carefully balanced hydrodynamic environment controlling sediment and nutrient supply (Dorschel et al., 2009; Mienis et al., 2007; Roberts et al., 2006). Canyons play a critical role since they are the most important mechanism of nutrient input into the deep marine environment (Canals et al., 2006; de Stigter et al., 2007; Duineveld et al., 2001; Palanques et al., 2009). Moreover, due to frequent incisions during glacial sea-level lowstands (Bourillet et al., 2006; Cunningham et al., 2005; Toucanne et al., 2009; Zaragosi et al., 2000), the eroded canyon flanks may offer a peculiar environment which is beneficial for settling of sessile organisms since they profit from the enhanced nutrient flux. Already in the late $19^{\text {th }}$ and the mid- $20^{\text {th }}$ century fisheries research had demonstrated the presence of coldwater corals in the vicinity of the canyons in the northern Bay of Biscay (Reveillaud et 
85

86

al., 2008). A first mapping and description of these Massifs coralliens (Fig. 1) was published by Le Danois (1948). Sporadically, scientists and fishermen also reported dredged oysters from this part of the margin, which was not given the appropriate attention at that time. Oysters are commonly referred to as typical shallow-water and occasionally reef-forming molluscs, but a number of samples have also been recovered from the deeper realm (Wisshak et al., 2009a). The existence of the deep-water oyster Neopycnodonte zibrowii was formally described in Wisshak et al. (2009a) based on submersible observations and sampling in the Azores archipelago between 2002 and 2007.

In this paper, we report and describe the physical and oceanographic setting of the northernmost and deepest occurrence of Neopycnodonte zibrowii oysters within two canyons along the French Atlantic margin (Fig. 1). Seabed observations with the Remotely Operated Vehicle (ROV) Genesis resulted in the discovery of giant deepwater oyster banks and cliffs in depths between 540 to $846 \mathrm{~m}$ (Table 1). These observations were performed with R/V Belgica during the HERMES Geo cruise in June 2006 (La Chapelle continental slope) and the BiSCOSYSTEMS cruise in June 2008 (Guilvinec canyon). The observed spatial distribution of the molluscs in relation to the slope morphology and local hydrographic regime gives an insight in the habitat requirements of this new species. This will be compared to the habitat requirements of another successful reef-forming organism: scleractinian cold-water corals.

\section{Regional setting}


99 The NE Atlantic continental margin in the Bay of Biscay can be divided in five main

100 areas: the Celtic and the Armorican margin in the north, and the Aquitaine, Cantabrian

101 and Galician margin in the south (Fig. 1). The morphology of the continental slope is

102 characterized by spurs and canyons, organized in drainage basins and actively feeding

103 the Celtic, Armorican and Cap Ferret deep-sea fans (Bourillet et al., 2003; Zaragosi et

104 al., 2000). However, between the Delesse $\left(47^{\circ} \mathrm{N}\right)$ and Conti Spur $\left(45^{\circ} \mathrm{N}\right)$, no significant

105 deep-sea fans are observed at the mouth of the lower (southern) valleys; only small

106 channel-levee complexes, slumps and small lobes are present (Bourillet et al., 2006).

108 Most of the water masses in the Bay of Biscay are of North Atlantic origin (Pollard et

109 al., 1996). The uppermost water mass is the Eastern North Atlantic (Central) Water

110 (ENAW), which extends to depths of about 400 to $600 \mathrm{~m}$. Although this water mass has

111 a salinity of 35.6, according to Pollard et al. (1996) there is a core of low density water

112 around $500 \mathrm{~m}$ water depth due to the lateral influence of the Subarctic Intermediate

113 Water (SAIW). Between 400 to $500 \mathrm{~m}$ and $1500 \mathrm{~m}$ water depth, the Mediterranean

114 Outflow Water (MOW) follows the continental slope as a contour current. Its

115 circulation is conditioned by seafloor irregularities and the Coriolis effect. MOW

116 velocities have been measured in the Bay of Biscay at $8^{\circ} \mathrm{W}$ and $6^{\circ} \mathrm{W}$ with minimum

117 values of 2-3 cm/s. Iorga and Lozier (1999) show that the MOW splits into two

118 branches as it passes Galicia Bank, and turns into the Bay of Biscay as a cyclonic

119 recirculation. Low salinity values observed on the Armorican continental slope may

120 reflect a depletion of the MOW core (Van Aken, 2000). Between 1500 and $3000 \mathrm{~m}$

121 water depth the North Atlantic Deep Water (NADW) is recognized. It includes a core of

122 the Labrador Sea Water (LSW) at a depth of about $1800 \mathrm{~m}$ down to $2000 \mathrm{~m}$ 
123 (McCartney, 1992; McCave et al., 2001; Vangriesheim and Khripounoff, 1990). Below

124 the NADW, the Lower Deep Water is identified, which mainly seems to result from the

125 mixing of the deep Antarctic Bottom Water and the Labrador Deep Water (Botas et al.,

126 1989; Haynes and Barton, 1990; Pingree and Le Cann, 1992; Van Aken, 2000).

128 Along the slopes of the Bay of Biscay strong, localized internal tides are reported,

129 resulting from a combination of favourable water mass stratification, steep topography

130 and strong barotropic tidal currents (Huthnance, 1995; Pairaud et al., 2008; Pingree and

131 Le Cann, 1989, 1990). As the slope is intersected with canyons, these tidally induced

132 transports may be channelled and result in regions of locally increased flow and local

133 circulations (Pingree and Le Cann, 1990). A dominant effect caused by internal tides

134 from the upper slope is proposed to explain the enhanced levels of surface

135 phytoplankton abundance (Holligan et al., 1985; Pingree et al., 1982).

\section{3. Material and methods}

138 The data for this study was acquired during two R/V Belgica expeditions in the Bay of

139 Biscay. A first cruise, HERMES Geo, focussed during only 3 days in June 2006 on the

140 La Chapelle continental slope (Fig. 1b). In June 2008, the BiSCOSYSTEMS cruise

141 surveyed the vicinity of the Guilvinec Canyon (Fig. 1c). During both cruises a

142 geophysical survey (multibeam bathymetry and seismic profiling) and CTD profiling

143 (Fig. 2) preceded the ROV observations.

\subsection{Geophysical survey}


146 Initial swath bathymetry coverage of both study areas was performed using the R/V

147 Belgica hull-mounted SIMRAD EM1002 multibeam echosounder. On the La Chapelle

148 continental slope, an area of $71.7 \mathrm{~km}^{2}$ was mapped in water depths ranging from 200 to

$149950 \mathrm{~m}$ (Fig. 1b) and processed using the IFREMER CARAIBES software. In 2008, an

150 area of $584 \mathrm{~km}^{2}$ was mapped around the Guilvinec canyon in water depths ranging from

151180 to $1000 \mathrm{~m}$ (Fig. 1c). The 2008 dataset was processed using MB-Systems and IVS

152 Fledermaus software. Both datasets were gridded to a cell size of 20 by $20 \mathrm{~m}$ and

153 visualized using GMT version 4.2 (Wessel and Smith, 1991).

155 In order to obtain insight in the sedimentary processes and the thickness of the sediment

156 cover, single channel seismic profiles were acquired using a SIG sparker source at a

157 velocity of 3 knots (Figs. 1c and 3). The source was triggered every 3 s, reaching $500 \mathrm{~J}$

158 energy. The vertical resolution of the profiles varies between 1 and $2 \mathrm{~m}$. A basic

159 processing (band-pass filtering, automatic gain control) was applied using PROMAX

160 software.

161

\subsection{Water mass characterization}

163 At both sites, information regarding the water mass stratification was obtained using a

164 SEACAT SBE 19 CTD down to water depths of about $1400 \mathrm{~m}$ (Table 2, Fig. 2). The

165 raw data was binned at $1 \mathrm{~m}$ using SBE Data Processing (version 7.16a). The obtained

166 temperature $\left({ }^{\circ} \mathrm{C}\right.$ ), salinity and potential density (sigma-theta, $\mathrm{kg} / \mathrm{m}^{3}$ ) were used to

167 identify the water masses and to indicate the relationship between deep-water oyster

168 occurrence and hydrography (Fig. 2). 


\section{0 \\ 3.3 ROV observations}

171 The ROV observations (Table 1, video files as online supplementary material) were

172 performed using Ghent University's ROV Genesis, a Sub Atlantic Cherokee type ROV

173 with a Tethered Management System (TMS) allowing investigations down to $1400 \mathrm{~m}$

174 water depth. The underwater positioning was obtained using an IXSEA GAPS USBL

175 system, allowing an accuracy in the order of $2 \mathrm{~m}$. Seafloor observations were made by

190 The CTD casts show a similar water mass stratification in both study areas (Fig. 2). The 191 seasonal thermocline is recognized down to $50 \mathrm{~m}$ water depth (Figs. 2b-c). A salinity means of a forward-looking colour zoom and black \& white video camera, assisted by $>$ 250 Watt Q-LED illumination. A laser marker was added to the camera head for scale (10 cm spacing). High-resolution images were acquired using a digital Canon

Powershot stills camera. Unfortunately, due to a malfunctioning during the June 2006 campaign, images were derived from video capture instead of the stills camera. The processing and interpretation of dive B06-02 was performed in an ArcGIS environment, expanded with the Adélie extension for ArcGIS 9.0 developed at IFREMER (http://www.ifremer.fr/flotte/systemes_sm/adelie/index.html). Dives B08-02 and B0805 were interpreted using OFOP (Ocean Floor Observation Protocol) version 3.2.0c (Huetten and Greinert, 2008) and integrated into ArcGIS.

\section{Results}

\subsection{Environmental setting}

\subsubsection{Hydrography} minimum $( \pm 35.58)$ at about $550 \mathrm{~m}$ separates the upper Eastern North Atlantic Water (ENAW) from the saline Mediterranean Outflow Water (MOW), which has its salinity 
194 maximum $( \pm 35.76)$ at about $1000 \mathrm{~m}$. Below, the T/S profile gradually follows the 27.75

$195 \mathrm{~kg} / \mathrm{m}^{3}$ potential density gradient towards the LSW and NADW.

\subsubsection{Geomorphology}

198 The morphology of the La Chapelle continental slope is characterized by spurs and 199 canyons (Fig. 1b). This study was carried out around a central, yet unnamed spur,

200 flanked by deep canyons and thalweg channels in surveyed water depths from 150 to

$2011100 \mathrm{~m}$. It has a main NE-SW orientation and an average inclination of $2^{\circ}$. Based on 202 our discoveries, we suggest the name Ostrea Spur for this morphological feature. The 203 slopes flanking the spur show a ,herringbone' pattern of WNW-ESE orientated gullies 204 on the western slope $\left(13-15^{\circ}\right)$ and NNW-SSE orientated gullies on the eastern slope $205\left(16^{\circ}\right)$

207 The Armorican margin near the Guilvinec Canyon is characterised by a heavily incised 208 slope with NE-SW oriented canyons and spurs (Fig. 1). The Guilvinec Canyon is $14 \mathrm{~km}$ 209 wide and bound to the northwest by the Penmarc'h Spur. The main part of this spur is 210 relatively flat $\left(0-2^{\circ}\right)$ until $250 \mathrm{~m}$ water depth. Here, the gradient towards the Guilvinec

211 Canyon is rather abrupt $\left(10^{\circ}\right)$, especially along its relatively steep northern to north-

212 western flanks $\left(30-40^{\circ}\right)$. This flank contains about 4 large dendritic gully systems with a

213 NNW-SSE orientation. In contrast, the eastern flank of the canyon is much smoother

214 (and less incised) with slope gradients ranging from 5 to maximum $20^{\circ}$. This

215 asymmetry is also observed on the seismic profiles (Figs. 1c and 3). Figure $3 \mathrm{~b}$ shows a

216 seismic profile through the largest $\left(1 \mathrm{~km}\right.$ wide) and steepest $\left(17-35^{\circ}\right)$ gully, which was

217 also the subject of ROV dive B08-02 (Fig. 1c). Exclusively on the SE flank, a large 
218 (200-400 ms TWT) sigmoidal depositional sequence can be observed which explains

219 the smoother slope texture. A comparison with other regional seismic stratigraphic

220 studies (Bourillet et al., 2003; Paquet et al., 2010) suggests that this sequence may be

221 correlated with the Pliocene to Pleistocene Little Sole Formation. On the other hand,

222 almost the entire NW flank is covered with diffraction hyperbolae, suggesting erosive

223 steep slopes, irregular topography or outcropping hard substratum. These deeper strata

224 may have a Miocene origin, belonging to the Jones or Cockburn Formations (Bourillet

225 et al., 2003). Along the south-western tip of the spur, 6 more gullies can be observed

226 within the prolongation of the spur's axis. These gullies are approximately $400-500 \mathrm{~m}$

227 wide and have a gradient between 10 to $25^{\circ}$.

\subsection{ROV observations}

\subsubsection{Dive B06-02: Eastern flank of Ostrea Spur}

231 Dive B06-02 followed a SW-NW, $2800 \mathrm{~m}$ long track over the eastern flank of the

232 Ostrea Spur, parallel to its elongation, crossing several of the steep $\left(16^{\circ}\right) \mathrm{NNW}-\mathrm{SSE}$

233 orientated gullies on the eastern slope (Fig. 4). The main observations were carried out

234 on the central gully between $7^{\circ} 20^{\prime} 00^{\prime \prime} \mathrm{W}$ and $7^{\circ} 19^{\prime} 40^{\prime \prime} \mathrm{W}$, allowing a more

235 comprehensive view on the gully environment.

237 A large part of the dive trajectory (57\%) showed sandy bioturbated sediments with 238 ripple marks on the relatively flat gully shoulders (Figs. 4 and 5a). These fairly straight

239 NW-SE oriented sand ripples have wavelengths of approximately $10-20 \mathrm{~cm}$ and are less

240 than $10 \mathrm{~cm}$ high. On other locations outside the gully axis, an enigmatic pale-coloured

241 facies was observed featuring decimetric to metric blocks or knolls inferred to be 
carbonated material (Fig. 5b). No recent sediment cover was observed and frequently yellow Hexadella sp. sponges were noticed on top these blocks, which were observed over $25 \%$ of the track length.

Protruding banks with a thickness ranging from 10 to $30 \mathrm{~cm}$ were observed regularly, especially on the steep slopes within the central part of the dive between 620 and $680 \mathrm{~m}$ (Figs. 5c-d). They form steps down to the central gully thalweg along a NNE-SSW to NW-SE orientation (Fig. 4). In total, 20 laterally variable banks were encountered over $60 \mathrm{~m}$ depth. Towards the centre of the gully they disappear into a large N-S oriented escarpment between 630 and $650 \mathrm{~m}$ water depth (Fig. 5f). Based on our observations, this escarpment cliff is at least $10 \mathrm{~m}$ high. The ensemble of this steep environment represents about $16 \%$ of the track length. At the base of this cliff and above the larger banks, accumulated debris provides settling sites for sessile organisms, whilst the escarpment and the larger protruding banks are sporadically colonized by medium to dense communities of giant (10-15 cm) Neopycnodonte zibrowii oysters (Figs. 5d-e), forming a 3D assemblage with occasional dead cold-water corals (Lophelia pertusa), which occur very rarely. The oysters only occur in high densities (up to 100 individuals per $\mathrm{m}^{2}$ ) near the centre of the gully between 620 and $680 \mathrm{~m}$, while they were also observed in a similar setting at 4 other locations between 540 to $680 \mathrm{~m}$ (Fig. 4). Most typically, at the side of the gully, they only occur underneath overhanging banks which protrude far enough $(10-15 \mathrm{~cm})$ from the seafloor. Only 9 of the observed banks were large enough to offer sufficient space for closely stacked shells, literally hanging in a density of about 30 individuals per $\mathrm{m}^{2}$ (Fig. 5e). Near the escarpment, they act as a highdensity vertical wall pavement (Fig. 5f). Many oyster individuals are still articulated and 
266 alive, or, where the free right valve is detached, show the non-degraded and locally still

267 dark-coloured endostracum indicating that these oysters died only recently (Fig. 5e).

268

\subsubsection{Dive B08-02: North-western flank of Guilvinec Canyon}

Dive B08-02 covered $3700 \mathrm{~m}$ of seafloor observations along a U-shaped track starting with the first "leg" southwards from the NE flank of a gully at $700 \mathrm{~m}$ water depth and ending with a second "leg" parallel to the gully axis (Figs. 1c and 6). The seabed slope along this track has an average gradient of $11^{\circ}$.

Along the main part of the dive track, a featureless bioturbated sandy seafloor was observed. Nevertheless, the easternmost part of the track which is roughly following $5^{\circ} 22^{\prime} 50^{\prime \prime} \mathrm{W}$, revealed the presence of abundant yellow Hexadella sp. sponges, live Madrepora oculata patches or fossil Lophelia pertusa debris (Fig. 6). Since the distribution, diversity and habitat settings of cold-water corals along this part of the Armorican margin are discussed in detail by De Mol et al. (accepted), only their occurrence and substratum are described in this section. These are predominantly solitary cold-water corals and represent about $40 \%$ of the observations. The present-day community is not forming close reef-like structures, but can be found on dead coldwater coral rubble "graveyards" (De Mol et al., accepted). Further observed substrates for the cold-water corals include a sandy rippled seabed, buried biogenic rubble and erratic boulders. Common, co-occurring organisms associated to the cold-water corals are sea-pens, sea-urchins, sponges and soft corals (De Mol et al., accepted). 
289 Between 800 and $950 \mathrm{~m}$, a rippled seabed was frequently encountered (10\% of the

290 observations). Especially below 900 m, straight and sometimes sinuous N-S oriented

291 low-relief sand ripples were observed with wavelengths ranging between $10-20 \mathrm{~cm}$ and

292 heights of approximately $5 \mathrm{~cm}$ (Figs. 6 and 7c). Additionally, relatively intense

293 flocculation was noted (Fig. 7c).

295 Only sporadically (less than $5 \%$ of the observations), the rather smoothly sloping seabed

296 is interrupted by small banks or escarpments (Figs. 6 and 7a-b). These escarpments are

297 long "ruptures" in the seabed, showing a consolidated subtrate and having an E-W

298 orientation between 700 and $750 \mathrm{~m}$, while the ones located deeper than $750 \mathrm{~m}$, usually

299 show a S-N or SSW-NNE orientation. Generally, the banks have a decimetric scale,

300 while the heights of the escarpments range between 2 to $4 \mathrm{~m}$. On only at three out of

301 nine locations (Figs. 6 and 7a-c), the escarpments were colonized by Neopycnodonte

302 zibrowii oysters and, in lesser degree, by Madrepora oculata. However, compared to

303 dive B06-02 on Ostrea Spur, the abundance of Neopycnodonte zibrowii on the

304 escarpments (Figs. 7a-b), is far less with 10 to 30 individuals per $\mathrm{m}^{2}$. A relatively

305 abundant community of deep-water oysters (100 individuals per $\left.\mathrm{m}^{2}\right)$ is only observed at

306 a water depth of $744 \mathrm{~m}$ at the leeward side of a $1 \mathrm{~m}$ high W-E overhanging escarpment.

307 Here, the top $40 \mathrm{~cm}$ underneath the edge is colonized. Madrepora oculata was observed

308 on top of the escarpment's edge.

310 4.2.3 Dive B08-05: Western flank of Guilvinec Canyon

311 Dive B08-05 mainly investigates the southern shoulder of a gully south of the spur that

312 separates the Guilvinec from the Penmarc'h Canyon (Figs. 1c and 8). The $3100 \mathrm{~m}$ long 
313 track followed a southwest course between 300 and $750 \mathrm{~m}$ water depth. The overall

314 gradient of the slope is $8-10^{\circ}$.

315

316 In contrast with the other dive tracks, this last track does not show a lot of variability in

317 the encountered facies (Fig. 8). Between 300 and $450 \mathrm{~m}$, the gently dipping slope is

318 characterized by the presence of straight to gently undulatory sand ripples with a

319 wavelength between 10 to $15 \mathrm{~cm}$ and a general SSE-NNW orientation (Fig. 9a), making

320 up $37 \%$ of the observations. Sometimes coarser sand was observed in between the

321 ripples. From 450 to $730 \mathrm{~m}$, a relatively flat and bioturbated silty to sandy seafloor is

322 observed with some small escarpments near $480 \mathrm{~m}$ and a low-relief rippled seabed (Fig.

$3238)$.

324

325 Only at the very end of Dive B08-05, the gentle slope is abruptly interrupted by a large,

326 laterally continuous $4 \mathrm{~m}$ high WSW-ENE rocky escarpment at $735 \mathrm{~m}$. The first meter of

327 this escarpment is a $50 \mathrm{~cm}$ deep overhanging cliff underneath which a thriving

328 community of Neopycnodonte zibrowii oysters, singular Madrepora oculata and some

329 sponges can be observed (Figs. 9b-c). Figure 9d shows the typical high-density

330 assemblage of Neopycnodonte zibrowii which seem to have grown on top of each other.

331 Their size amounts to $10 \mathrm{~cm}$ on the smallest axis and $15 \mathrm{~cm}$ on the largest axis. The

332 density is estimated at 63 individuals per $\mathrm{m}^{2}$. Both the oysters as the occasional corals

333 are hanging "upside down", concentrated near the most overhanging end of the cliff.

\section{Discussion}


336 The main part of the discussion is based on the observations made during ROV dive

337 B06-02 along the La Chapelle continental margin, since it has provided the best

338 overview of the occurrence of Neopycnodonte zibrowii in relation with the canyon

339 environment (Fig. 10). The observations from Guilvinec canyon will be used as

340 additional information. The habitat in which these giant deep-water oysters are thriving

341 is dependent on both specific morphological and environmental conditions.

\subsection{The occurrence of deep-water oysters in the Atlantic Ocean}

344 These large deep-water oysters (up to $20 \mathrm{~cm}$ ) belong to the recently described species

345 Neopycnodonte zibrowii (Wisshak et al., 2009a, 2009b), which so far has only been

346 documented alive from the Azores. The use of ROV technology enabled detailed

347 observations of its deep-water habitat in a sheltered environment. Unfortunately, during

348 none of the two R/V Belgica cruises samples could be acquired for morphological or

349 molecular taxonomy. Nevertheless, corresponding alive oysters were observed and

350 sampled with submersible aid at the Azores and were described - together with material

351 recovered during $\mathrm{R} / \mathrm{V}$ Thalassa expeditions in the early seventies from the southern Bay

352 of Biscay - as a new species of Neopycnodonte by Wisshak et al. (2009b). Previous

353 observations of mostly dead or sub-fossil specimens were only reported from dredge

354 samples or fisheries by-catch (Le Danois, 1948; Reveillaud et al., 2008). Further

355 isolated records of this species stem from the Gorringe Bank off Portugal (Auzende et

356 al., 1984), south of Madeira (Hoernle et al., 2001) and in the Central Mediterranean Sea

357 where they occur as prominent (sub-) fossil oyster banks (Gofas et al., 2007). This

358 „living fossil' oyster is most unusual with respect to its habitat, size, geochemical

359 signature and its particularly pronounced centennial longevity (Wisshak et al., 2009a, 
360 2009b). It stands in strong contrast to all other extant oyster species which are relatively

361 short-lived and predominantly occupy shallow to marginal marine settings, where they

362 occasionally form reefal structures. From the upper slope (200-500 m) of the Bay of

363 Biscay, the related but smaller $(4-5 \mathrm{~cm})$ Neopycnodonte cochlear has been reported (Le

364 Danois, 1948). The latter is usually associated with hard substrates and in certain places

365 colonizes Dendrophyllia cornigera coral reefs (Le Danois, 1948). N. cochlear certainly

366 features the largest distribution worldwide, both in palaeo- (Videt and Neraudeau, 2003)

367 and present-time environments (Harry, 1981). Neopycnodonte zibrowii, observed alive

368 along the La Chapelle continental slope, the Guilvinec Canyon and off the Azores can

369 be regarded as a distinct deep-sea relative of $N$. cochlear with specific adaptations

370 allowing it to thrive in upper bathyal depths (now confirmed down to $846 \mathrm{~m}$ ), and it can

371 be expected that further direct seabed observations will considerably enhance the known

372 biogeographic distribution of this unusual bivalved mollusc. Most recently,

373 Delongueville and Sciallet (2009), reinvestigated two unusually large specimens

374 sampled alive from the Bay of Biscay margin, previously addressed as Neopycnodonte

375 cochlear (Delongueville and Sciallet, 1999), which can now be attributed to

376 Neopycnodonte zibrowii. Interestingly, they were recovered from a water depth of only

377350 to $400 \mathrm{~m}$, expanding the known bathymetrical range of this species in the Bay of

378 Biscay from 350 to 846 metres. In contrast to the Azores, both Biscay pycnodontines

379 overlap in their bathymetrical range.

\subsection{Influence of the physical environment on deep-water oyster colonization}

382 Up to now, the occurrence of the deep-water oyster Neopycnodonte zibrowii within the

383 Bay of Biscay has only been observed on hard substrates. More specifically, the area 
384 underneath overhanging cliffs, banks or steep escarpments seem to be the most

385 successful colonization surface (Figs. 5, 9 and 7). This is in contrast with the local

386 occurrence of other sessile organisms such as cold-water corals (M. oculata and $L$.

387 pertusa) and sponges, which are abundantly present on open parts of the slope (Fig. 6).

388 They have settled on sandy substrate, biogenic debris and on top of elevated substrates,

389 such as documented for this area by De Mol et al. (accepted) and along the NW

390 European margin (Dorschel et al., 2009; Freiwald et al., 2004; Huvenne et al., 2005;

391 Wheeler et al., 2007). Only occasionally, and in reduced numbers, they can be found on

392 identical substrates colonized by the deep-water oysters (Figs. 7b and 9b). In this case,

393 such vertical substrates and overhangs could be considered as a challenging surface to

394 be colonized by cold-water corals. Such specific substrates can be considered as limited

395 along the continental margins and are specifically concentrated within deep-sea

396 canyons, where they still are relatively sparsely distributed (less than 5\% in this

397 dataset).

398

399 Generally, the morphology of canyons flanks is relatively irregular and no significant

400 cover of draping sediments is observed. This zone is most likely subject to constant

401 reworking by downslope (turbiditic) or alongslope (contouritic) current processes

402 (Arzola et al., 2008; Bourillet et al., 2006; Cunningham et al., 2005; Huthnance, 1995;

403 Pingree and Le Cann, 1989; Toucanne et al., 2009). Within the depth window

404 corresponding to the ROV observations, seismic profiles show single, high-amplitude

405 reflections or diffraction hyperbolae that might indicate the presence of lithified

406 calcarenite or calcilutites banks (Figs. 3, 10) which possibly belong to the Miocene

407 Jones or Cockburn Formations (Bourillet et al., 2003; Paquet et al., 2010). Within 
408 canyons and gullies, predominantly downslope erosion has gradually exposed these 409 consolidated carbonate-like sedimentary sequences, which have been shaped into step-

410 like banks or escarpments. This process is more intensive towards the centre (thalweg)

411 of the canyon or gully, providing a higher availability of suitable substrates for

412 epibenthos colonization (Fig. 10). Evidently, this will also affect the communities of the

413 sessile organisms that colonize these substrates. If they are too exposed, the epifauna

414 may be removed by the episodic downslope currents. The overhanging banks and the

415 vertical escarpments may provide a sufficiently sheltered habitat for the deep-water

416 oysters, which are capable to settle on such surfaces. However, this particular habitat

417 does not allow plenty of co-occurring species such as cold-water corals which

418 necessitate the current exposure. Along the steeper slopes of the La Chapelle continental

419 slope, relatively more suitable substrates with large deep-water oyster communities

420 were observed, compared to the Guilvinec area. Moreover, almost no observations were

421 made of cold-water corals, while they are abundantly present on the gentler Guilvinec

422 slope (Figs. 4 and 6).

423

424 Additionally, the asymmetry of the Guilvinec Canyon clearly demonstrates a second

425 factor influencing the location of the deep-water oyster habitats. Both morphologically

426 and stratigraphically the (north-) western slope of the Guilvinec Canyon shows more

427 evidence of erosion than the eastern slope, which is characterized by depositional

428 features (Figs. 1c and 3). ROV observations have shown the presence of seabed ripples

429 on different parts of this slope between 300 and $950 \mathrm{~m}$ (Figs. 6 and 8), suggesting the

430 presence of an E-W bottom current with velocities between 20 and $40 \mathrm{~cm} / \mathrm{s}$ (Stow et al.,

431 2009). These observations fit the cyclonic flow circulation and observed depth of the 
432 MOW in the Bay of Biscay (Fig. 2). The (north-)western slope of the canyon(s) could

433 act as an obstacle which might intensify the easterly bottom currents through isopycnal

434 doming, leading to erosion (Hernández-Molina et al., 2003; Iorga and Lozier, 1999; Van

435 Rooij et al., submitted). A similar process was also observed on the upper part of the

436 Portimao Canyon (Marches et al., 2007). As such, this effect is not present on the

437 eastern slope, leading to preferential deposition on this side of the canyon, making it

438 nearly devoid of banks and escarpments. This example also proves that a combined

439 influence of turbiditic and contouritic currents may shape the canyon morphology and

440 hence determine the location of preferential habitats of (hidden) deep-water ecosystems.

441 Both the banks as the cliffs will not easily be subject to sediment burial and provide a

442 suitable hard substrate for this type of filter feeders. As such, there is not much

443 competition between the deep-water oysters and cold-water corals, since they seem to

444 have slightly different physical habitat requirements.

$446 \quad 5.3$ Oceanographic drivers for deep-water oyster occurrence

447 Next to the necessary settling grounds, a successful oyster habitat needs the suitable

448 oceanographic environment and sufficient nutrients. During some of the ROV dives, an

449 intense marine snow was present in the area where the oyster community was

450 discovered (Figs. 5a, 7c-d and 9c). This aggregated particulate matter composed of

451 phytodetritus and pellets, sinking from the upper water layers, constitutes an important

452 aspect in the trophic input of this community. Oysters are filter feeders, commonly

453 located in low salinity coastal shallow water and feeding on phytoplankton. The

454 occurrence of oysters at these depths is at least remarkable given the higher salinities

455 and generally lower input of phytodetritus. On the other hand, a relatively high surface 
456 primary production is present along this part of the margin (Joint et al., 2001; Pingree

457 and Le Cann, 1990). Moreover, according to the available hydrographic data, the depth

458 range in which Neopycnodonte zibrowii is observed lies just beneath the physical

459 boundary between the upper Eastern North Atlantic Water and the intermediate saline

460 Mediterranean Outflow Water (Fig. 2). The lower limit of the oyster's occurrence

461 coincides with a local salinity and temperature maximum of respectively 35.75 and

$46210^{\circ} \mathrm{C}$, which might indicate a certain amount mixing of both water masses. Within this

463 zone of upper MOW, seabed features indicate a locally vigorous hydrodynamic

464 environment near the gully shoulders (Figs. 4, 6 and 8). The observations of straight

465 sand ripples during dive B06-02 indicate the presence of strong bottom currents

466 between 10 and $40 \mathrm{~cm} / \mathrm{s}$ (Stow et al., 2009). Apart from the flow velocity of the MOW,

467 the bottom currents may be enhanced by strong internal tides (White, 2007) and

468 funnelled along the canyon axis, as observed in the Portimao Canyon (Marches et al.,

469 2007). This is consistent with previous measurements along the Armorican margin

470 (Pingree and Le Cann, 1989, 1990), where a strongest bottom current near the $500 \mathrm{~m}$

471 contour was observed in the downslope direction with a maximum instantaneous

472 velocity of $95 \mathrm{~cm} / \mathrm{s}$. Intersected with canyons, these tidally induced transports may be

473 channelled and result in regions of locally increased flow, resuspension and local

474 circulations (Pingree and Le Cann, 1990). A dominant effect caused by internal tides

475 from the upper slope is proposed to explain the entrapment and downward transport of

476 the enhanced levels of surface phytoplankton abundance (Holligan et al., 1985; Pingree

477 et al., 1982) as recently inferred above the Nazaré Canyon (Arzola et al., 2008) and

478 above giant carbonate mound provinces colonised by reef-forming cold-water corals

479 (Mienis et al., 2007; White, 2007). The significance of submarine canyons as coral and 
480 oyster habitats (Mortensen and Buhl-Mortensen, 2005) may be due to their capacity to

481 accumulate organic debris (Canals et al., 2006), which may directly benefit filter-

482 feeders, such as scleractinians (Roberts et al., 2006). It is highly likely that this water-

483 mixing above the seabed results in enhanced suspended material and favours

484 concentration of filter/suspension feeders (de Stigter et al., 2007).

485

486 Moreover, the oyster banks occur in a potential density envelope of $27.4-27.7 \mathrm{~kg} / \mathrm{m}^{3}$

487 (Fig. 2), overlapping the range of values which are considered to be a prerequisite for 488 the development, growth and distribution of cold-water coral reefs along the Celtic and 489 Nordic European margin (Dullo et al., 2008) and within the Guilvinec area (De Mol et 490 al., accepted). This control through potential density may be linked to the formation of 491 intermediate nepheloid layers, which increase nutrient supply and resuspension (de 492 Stigter et al., 2007; Mienis et al., 2007). As such, in contrast to the shallow marine 493 oyster occurrences, the dynamic oceanography within deep-sea canyons can provide a

494 stable ecosystem which enables a theoretical co-habitation with sponges, hydrozoans, 495 gorgonians and scleractinians (De Mol et al., accepted).

497 6. Conclusions

498 In this paper, the occurrence and the environmental drivers of a hidden deep-water 499 habitat (540-846 m), inhabited by Neopycnodonte zibrowii oysters along the French

500 Atlantic continental margin, is described. The present observations indicate that canyons

501 and steep slopes may provide the most suitable physical environment for these oysters,

502 which are predominantly observed underneath overhanging banks or on escarpments.

503 Turbiditic and contouritic processes are responsible for (1) the erosion which exposes 
504 consolidated carbonate-like sedimentary sequences, shaping them into step-like banks,

505 and (2) the delivery and resuspension of nutrients in association with funnelling of

506 internal tides into canyons. Although these deep-water oysters occur in a similar

507 oceanographic setting as cold-water corals, their very specific physical habitat

508 requirements do not seem to be fully compatible with most of the other sessile

509 organisms. Once these rather strict and sparsely distributed environments are

510 encountered, Neopycnodonte zibrowii can be observed in relatively high number up to

511100 individuals per $\mathrm{m}^{2}$.

512

513 This little-known population located in an inaccessible environment sheds light on the

514 richness of canyon systems in terms of filter feeder species. Because of the verticality of

515 this habitat, acoustic hull-mounted systems and bottom sampling with conventional

516 towed devices will be unsuitable for a fine description of this population. As such,

517 further in situ observations and habitat mapping from ROV's should be performed to

518 estimate the oyster coverage along the Bay of Biscay and other Atlantic canyons. They

519 may represent an overlooked deep-water community, being part of a still vastly

520 underestimated biodiversity of bathyal benthic communities, especially within canyons.

\section{Acknowledgements}

523 This research was supported by the HERMES project (EC contract $n^{\circ}$ GOCE-CT-

524 2005-511234), funded by the European Commission's Sixth Framework Programme

525 under the priority ,Sustainable Development, Global Change and Ecosystems' and by

526 ESF EuroDIVERSITY MiCROSYSTEMS (05_EDIV_FP083-MICROSYSTEMS). A

527 follow-up of this research will be performed within the framework of the EC FP7 IP 
528 HERMIONE project (grant agreement $n^{\circ} 226354$ ). We are indebted to the entire ROV

529 Genesis technical team of Ghent University (Belgium). The captains, crews and

530 shipboard scientific parties of the R/V Belgica ST0612 and ST0813a campaigns are also

531 acknowledged for their enthusiastic efforts. We are grateful to Dr. L. Chou (ULB,

532 Belgium) for kindly providing CTD data (Station 3 cast B). The authors also kindly

533 acknowledge $\mathrm{H}$. Pirlet, in addition to 4 anonymous reviewers, for the useful comments

534 and suggestions which helped improving this manuscript. LDM acknowledges the

535 support through an IWT-grant. The research of DVR was funded through an FWO

536 Flanders post-doctoral fellowship.

538 Appendix A. Supplementary material

539 Supplementary data associated with this article can be found in the online version at...

\section{$541 \quad$ References}

542 Arzola, R.G., Wynn, R.B., Lastras, G., Masson, D.G., Weaver, P.P.E., 2008.

Sedimentary features and processes in the Nazaré and Setúbal submarine canyons, west Iberian margin. Marine Geology, 250(1-2), 64-88.

Auzende, J.-M., Charvet, J., Le Lann, A., Le Pichon, X., Monteiro, J.-H., Nicolas, A., Olivet, J.-L., Ribeiro, A., 1984. Géologie du Banc de Gorringe, Campagne CYAGOR II. Résultats des Campagnes à la Mer 27. Publications du Centre National pour l'Exploration des Oceans (CNEXO), Brest, 65 pp.

Botas, J.A., Férnandez, E., Bode, A., Anadón, R., 1989. Water masses off central Cantabrian coast. Scientia Marina, 53, 755-761. 
551 Bourillet, J.F., Reynaud, J.Y., Baltzer, A., Zaragosi, S., 2003. The 'Fleuve Manche': the submarine sedimentary features from the outer shelf to the deep-sea fans. Journal of Quaternary Science, 18(3-4), 261-282.

Bourillet, J.F., Zaragosi, S., Mulder, T., 2006. The French Atlantic margin and deep-sea submarine systems. Geo-Marine Letters, 26(6), 311-315.

Canals, M., Puig, P., de Madron, X.D., Heussner, S., Palanques, A., Fabres, J., 2006. Flushing submarine canyons. Nature, 444(7117), 354-357.

Cunningham, M.J., Hodgson, S., Masson, D.G., Parson, L.M., 2005. An evaluation of along- and down-slope sediment transport processes between Goban Spur and Brenot Spur on the Celtic Margin of the Bay of Biscay. Sedimentary Geology, $179,99-116$.

Delongueville, C., Sciallet, R. 1999. Neopycnodonte cochlear (Poli, 1795) dans le Golfe de Gascogne. Arion 24(2), 62

Delongueville, C., Sciallet, R. 2009. Neopycnodonte zibrowii Gofas, Salas \& Taviani in Wisshak et al., 2009 dans le golfe de Gascogne. Novapex 10(1), 9-12.

De Mol, L., Van Rooij, D., Pirlet, H., Greinert, J., Frank, N., Quemmerais, F., Henriet, J.P., the R/V Belgica 08/13a shipboard scientific party, accepted. Cold-water coral habitats in the Penmarc'h and Guilvinec canyons (Bay of Biscay): deepwater versus shallow water settings. Marine Geology.

de Stigter, H., Boer, W., de Jesus Mendes, P.A., Jesus, C.C., Thomsen, L., van den Bergh, G.D., van Weering, T.C.E., 2007. Recent sediment transport and deposition in the Nazaré Canyon, Portuguese continental margin. Marine Geology, 246, 144-164. 
574 Dorschel, B., Wheeler, A.J., Huvenne, V.A.I., de Haas, H., 2009. Cold-water coral mounds in an erosive environmental setting: TOBI side-scan sonar data and ROV video footage from the northwest Porcupine Bank, NE Atlantic. Marine Geology, 264(3-4), 218-229.

Duineveld, G., Lavaleye, M., Berghuis, E., de Wilde, P., 2001. Activity and composition of the benthic fauna in the Whittard Canyon and the adjacent continental slope (NE Atlantic). Oceanologica Acta, 24(1), 69-83.

Dullo, C., Flögel, S., Rüggeberg, A., 2008. Cold-water coral growth in relation to the hydrography of the Celtic and Nordic European continental margin. Marine Ecology Progress Series, 371, 165-176.

Freiwald, A., Fossa, J.H., Grehan, A., Koslow, T., Roberts, J.M., 2004. Cold-water coral reefs. Biodiversity Series. UNEP-WCMC, Cambridge, 84 pp.

Gofas, S., Freiwald, A., López Correa, M., Remia, A., Salas, C., Taviani, M., Wisshak, M., Zibrowius, H., 2007. Oyster beds in the deep sea. In: K. Jordaens, N. van Houtte, J. van Goethem, T. Backeljau (Eds), World Congress of Malacology, Antwerp, Belgium, pp. 80.

Halpern, B.S., Walbridge, S., Selkoe, K.A., Kappel, C.V., Micheli, F., D'Agrosa, C., Bruno, J.F., Casey, K.S., Ebert, C., Fox, H.E., Fujita, R., Heinemann, D., Lenihan, H.S., Madin, E.M.P., Perry, M.T., Selig, E.R., Spalding, M., Steneck, R., Watson, R., 2008. A global map of human impact on marine ecosystems. Science, 319(5865), 948-952.

Harry, H.W., 1981. Nominal species of living oysters proposed during the last fifty years. Veliger, 24, 39-45. 
597 Haynes, R., Barton, 1990. A poleward flow along the Atlantic coast of the Iberian 598 Peninsula. Journal of Geophysical Research, 95, 11425-11441.

Hernández-Molina, J., Llave, E., Somoza, L., Fernandez-Puga, M.C., Maestro, A.,

600

601

602

603

604

605

606

607

608

609

610

611

612

614

615

616

617

618

619

620

Leon, R., Medialdea, T., Barnolas, A., Garcia, M., del Rio, V.D., Fernandez-

Salas, L.M., Vazquez, J.T., Lobo, F., Dias, J.M.A., Rodero, J., Gardner, J., 2003.

Looking for clues to paleoceanographic imprints: A diagnosis of the Gulf of Cadiz contourite depositional systems. Geology, 31(1), 19-22.

Hoernle, K., Shipboard party, 2001. METEOR Cruise No. M51, Leg 1, VULKOSO Vulkanismus Ostatlantik-Alboran. GEOMAR, Bremen, 94 pp.

Holligan, P.M., Pingree, R.D., Mardell, G.T., 1985. Oceanic Solitions, Nutrient Pulses and Phytoplankton Growth. Nature, 314(6009), 348-350.

Huetten, E., Greinert, J., 2008. Software controlled guidance, recording and postprocessing of seafloor observations by ROV and other towed devices: the software package OFOP. Geophysical Research Abstracts, 10, EGU2008-A03088.

Huthnance, J.M., 1995. Circulation, exchange and water masses at the ocean margin: the role of physical processes at the shelf edge. Progress in Oceanography, 35, $353-431$

Huvenne, V., Beyer, A., de Haas, H., Dekindt, K., Henriet, J.P., Kozachenko, M., OluLe Roy, K., Wheeler, A., the TOBI/Pelagia 197 and CARACOLE cruise participants, 2005. The seabed appearance of different coral bank provinces in the Porcupine Seabight, NE Atlantic: results from sidescan sonar and ROV seabed mapping. In: A. Freiwald, J.M. Roberts (Eds.), Cold-water Corals and Ecosystems. Springer-Verlag, Berlin Heidelberg, pp. 535-569. 
621 Iorga, M.C., Lozier, M.S., 1999. Signatures of the Mediterranean outflow from a North

622

623

624

625

626

627

628

629

630

631

632

633

634

635

636

637

638

639

640

641

642

643
Atlantic climatology 1. Salinity and density fields. Journal of Geophysical

Research-Oceans, 104(C11), 25985-26009.

IPCC, 2007. Climate Change 2007: The Physical Science Basis. Contribution of

Working Group I to the Fourth Assessment Report of the Intergovernmental

Panel on Climate Change. Cambridge University Press, Cambridge, 996 pp.

Joint, I., Wollast, R., Chou, L., Batten, S., Elskens, M., Edwards, E., Hirst, A., Burkill, P., Groom, S., Gibb, S., Miller, A., Hydes, D., Dehairs, F., Antia, A., Barlow,

R., Rees, A., Pomroy, A., Brockmann, U., Cummings, D., Lampitt, R., Loijens, M., Mantoura, F., Miller, P., Raabe, T., Alvarez-Salgado, X., Stelfox, C., Woolfenden, J., 2001. Pelagic production at the Celtic Sea shelf break. Deep Sea Research Part II: Topical Studies in Oceanography, 48(14-15), 3049-3081.

Le Danois, E., 1948. Les profondeurs de la mer. Payot, Paris, 303 pp.

Marches, E., Mulder, T., Cremer, M., Bonnel, C., Hanquiez, V., Gonthier, E., Lecroart, P., 2007. Contourite drift construction influenced by capture of Mediterranean Outflow Water deep-sea current by the Portimao submarine canyon (Gulf of Cadiz, South Portugal). Marine Geology, 242(4), 247-260.

McCartney, M.S., 1992. Recirculating components to the deep boundary current of the northern North Atlantic. Progress in Oceanography, 29, 283-383.

McCave, I.N., Hall, I.R., Antia, A.N., Chou, L., Dehairs, F., Lampitt, R.S., Thomsen, L., van Weering, T.C.E., Wollast, R., 2001. Distribution, composition and flux of particulate material over the European margin at $47^{\circ}-50^{\circ} \mathrm{N}$. Deep-Sea Research II, 48, 3107-3139. 
644 Mienis, F., de Stigter, H., White, M., Duineveld, G.C.A., de Haas, H., van Weering, T., 645 2007. Hydrodynamic controls on cold-water coral growth and carbonate-mound development at the SW and SE Rockall Trough Margin, NE Atlantic Ocean. Deep-Sea Research I, 54, 1655-1674.

Mortensen, P., Buhl-Mortensen, L., 2005. Deep-water corals and their habitats in The Gully, a submarine canyon off Atlantic Canada. In: A. Freiwald, J.M. Roberts (Eds.), Cold-Water Corals and Ecosystems. Springer-Verlag, Berlin Heidelberg, pp. 247-277.

Pairaud, I.L., Lyard, F., Auclair, F., Letellier, T., Marsaleix, P., 2008. Dynamics of the semi-diurnal and quarter-diurnal internal tides in the Bay of Biscay. Part 1: Barotropic tides. Continental Shelf Research, 28(10-11), 1294-1315.

Palanques, A., Puig, P., Latasa, M., Scharek, R., 2009. Deep sediment transport induced by storms and dense shelf-water cascading in the northwestern Mediterranean basin. Deep-Sea Research I, 56(3), 425-434.

Paquet, F., Menier, D., Estournès, G., Bourillet, J.-F., Leroy, P., Guillocheau, F., 2010. Buried fluvial incisions as a record of Middle-Late Miocene eustasy fall on the Armorican Shelf (Bay of Biscay, France). Marine Geology, 268(1-4), 137-151.

Pingree, R.D., Le Cann, B., 1989. Celtic and Armorican slope and shelf residual currents. Progress in Oceanography, 23, 303-338.

Pingree, R.D., Le Cann, B., 1990. Structure, strength and seasonality of the slope currents in the Bay of Biscay region. Journal of the Marine Biological Association of the United Kingdom, 70, 857-885. 
666 Pingree, R.D., Le Cann, B., 1992. Three anticyclonic Slope Water Oceanic eDDIES

667

668

669

670

671

672

673

674

675

676

677

678

679

680

681

682

683

684

685

686

687

688

689

(SWODDIES) in the southern Bay of Biscay in 1990. Deep-Sea Research, 39, 1147-1176.

Pingree, R.D., Mardell, G.T., Holligan, P.M., Griffiths, D.K., Smithers, J., 1982. Celtic Sea and Armorican Current Structure and the Vertical Distributions of Temperature and Chlorophyll. Continental Shelf Research, 1(1), 99-116.

Pollard, S., Griffiths, C.R., Cunningham, S.A., Read, J.F., Perez, F.F., Ríos, A.F., 1996. Vivaldi 1991 - A study of the formation, circulation and ventilation of Eastern North Atlantic Central Water. Progress in Oceanography, 37, 167-192.

Reveillaud, J., Freiwald, A., Van Rooij, D., Le Guilloux, E., Altuna, A., Foubert, A., Vanreusel, A., Roy, K.O.L., Henriet, J.P., 2008. The distribution of scleractinian corals in the Bay of Biscay, NE Atlantic. Facies, 54(3), 317-331.

Roberts, J.M., Wheeler, A.J., Freiwald, A., 2006. Reefs of the Deep: The Biology and Geology of Cold-Water Coral Ecosystems. Science, 312(5773), 543-547.

Stow, D.A.V., Hernández-Molina, F.J., Llave, E., Sayago-Gil, M., del Rio, V.D., Branson, A., 2009. Bedform-velocity matrix: The estimation of bottom current velocity from bedform observations. Geology, 37(4), 327-330.

Toucanne, S., Zaragosi, S., Bourillet, J.F., Cremer, M., Eynaud, F., Van Vliet-Lanoë, B., Penaud, A., Fontanier, C., Turon, J.L., Cortijo, E., Gibbard, P.L., 2009. Timing of massive 'Fleuve Manche' discharges over the last 350 kyr: insights into the European ice-sheet oscillations and the European drainage network from MIS 10 to 2. Quaternary Science Reviews, 28(13-14), 1238-1256.

Van Aken, H.M., 2000. The hydrography of the mid-latitude Northeast Atlantic Ocean II: The intermediate water masses. Deep-Sea Research I, 47, 789-824. 
690 Van Rooij, D., Iglesias, J., Hernández-Molina, F.J., Ercilla, G., Gomez-Ballesteros, M., 691 Casas, D., Llave, E., De Hauwere, A., Garcia-Gil, S., Acosta, J., Henriet, J.-P., submitted. The Le Danois Contourite Depositional System: interactions between the Mediterranean Outflow Water and the upper Cantabrian slope (North Iberian margin). Marine Geology.

Vangriesheim, A., Khripounoff, A., 1990. Near-bottom particle concentration and flux: Temporal variations observed with sediment traps and nepholometer on the Meriadzek Terrace, Bay of Biscay. Progress In Oceanography, 24(1-4), 103-116.

Videt, B., Neraudeau, D., 2003. Variability and heterochronies of Rhynchostreon suborbiculatum (Lamarck, 1801) (Bivalvia : Ostreoidea : Gryphaeidae : Exogyrinae) from the Cenomanian and the Lower Taronian of Charentes (SW France). Comptes Rendus Palevol, 2(6-7), 563-576.

Weaver, P.P.E., Gunn, V., 2009. INTRODUCTION TO THE SPECIAL ISSUE HERMES Hotspot Ecosystem Research on the Margins of European Seas. Oceanography, 22(1), 12-15.

Wessel, P., Smith, W.H.F., 1991. Free Software helps Map and Display Data. EOS Transactions AGU, 72(441), 445-446.

Wheeler, A.J., Beyer, A., Freiwald, A., de Haas, H., Huvenne, V.A.I., Kozachenko, M., Olu-Le Roy, K., Opderbecke, J., 2007. Morphology and environment of coldwater coral carbonate mounds on the NW European margin. International Journal of Earth Sciences, 96, 37-56.

White, M., 2007. Benthic dynamics at the carbonate mound regions of the Porcupine Sea Bight continental margin. International Journal of Earth Sciences, 96, 1-9. 
713 Wienberg, C., Hebbeln, D., Fink, H.G., Mienis, F., Dorschel, B., Vertino, A., Correa,

M.L., Freiwald, A., 2009. Scleractinian cold-water corals in the Gulf of Cádiz--

721 First clues about their spatial and temporal distribution. Deep Sea Research I, 56(10), 1873-1893.

Wisshak, M., López Correa, M., Gofas, S., Salas, C., Taviani, M., Jakobsen, J., Freiwald, A., 2009a. Shell architecture, element composition, and stable isotope signature of the giant deep-sea oyster Neopycnodonte zibrowii sp. n. from the NE Atlantic. Deep Sea Research I, 56(3), 374-407.

Wisshak, M., Neumann, C., Jakobsen, J., Freiwald, A., 2009b. The 'living-fossil community' of the cyrtocrinid Cyathidium foresti and the deep-sea oyster Neopycnodonte zibrowii (Azores Archipelago). Palaeogeography, Palaeoclimatology, Palaeoecology, 271(1-2), 77-83.

Zaragosi, S., Auffret, G.A., Faugères, J.-C., Garlan, T., Pujol, C., Cortijo, E., 2000. Physiography and recent sediment distribution of the Celtic Deep-Sea Fan, Bay of Biscay. Marine Geology, 169, 207-237.

\section{Tables}

Table 1: Metadata of the ROV Genesis dive tracks

\begin{tabular}{|l|l|l|l|l|l|l|}
\hline \multirow{2}{*}{ Dive } & Location & \multicolumn{2}{|c|}{ Start } & \multicolumn{2}{c|}{ End } & \multirow{2}{*}{ Oyster } \\
\cline { 3 - 6 } \& Date & & Coordinates & Time \& & Coordinates & Time \& & depth \\
B06-02 & East flank & $47^{\circ} 33.34^{\prime} \mathrm{N}$ & $08: 31$ & $47^{\circ} 34.07^{\prime} \mathrm{N}$ & $15: 25$ & $540-$ \\
17 June & Ostrea Spur & $7^{\circ} 20.69^{\prime} \mathrm{W}$ & $587 \mathrm{~m}$ & $7^{\circ} 19.44^{\prime} \mathrm{W}$ & $557 \mathrm{~m}$ & $680 \mathrm{~m}$ \\
2006 & & & & & & \\
\end{tabular}




\begin{tabular}{|l|l|l|l|l|l|l|}
\hline B08-02 & North-western & $4^{\circ} 56.27^{\prime} \mathrm{N}$ & $11: 24$ & $46^{\circ} 55.72^{\prime} \mathrm{N}$ & $15: 46$ & $720-$ \\
1 June & flank & $5^{\circ} 22.89^{\prime} \mathrm{W}$ & $712 \mathrm{~m}$ & $5^{\circ} 22.90^{\prime} \mathrm{W}$ & $900 \mathrm{~m}$ & $846 \mathrm{~m}$ \\
\hline B08-05 & Guilvinec & & & & & \\
Canyon & Western flank & $46^{\circ} 55.68^{\prime} \mathrm{N}$ & $11: 17$ & $46^{\circ} 55.16^{\prime} \mathrm{N}$ & $14: 27$ & $737-$ \\
2008 & Guilvinec & $5^{\circ} 28.52^{\prime} \mathrm{W}$ & $305 \mathrm{~m}$ & $5^{\circ} 29.00^{\prime} \mathrm{W}$ & $737 \mathrm{~m}$ & $740 \mathrm{~m}$ \\
\hline
\end{tabular}

731

732 Table 2: Metadata of the CTD casts

\begin{tabular}{|l|l|l|l|l|l|}
\hline Name & Date & Location & Latitude & Longitude & Depth \\
\hline Station 3 cast B & 1 June 2006 & La Chapelle slope & $47^{\circ} 25.00^{\prime} \mathrm{N}$ & $7^{\circ} 16.00^{\prime} \mathrm{W}$ & $1396 \mathrm{~m}$ \\
\hline B0813-CTD-4 & 4 June 2008 & Guilvinec canyon & $46^{\circ} 54.53^{\prime} \mathrm{N}$ & $5^{\circ} 21.26^{\prime} \mathrm{W}$ & $1404 \mathrm{~m}$ \\
\hline
\end{tabular}

\section{Figure captions}

736 Figure 1: (a). Location of the study areas along the French Atlantic continental margin

737 (GEBCO bathymetry, contour lines every $250 \mathrm{~m}$ ), with indication of the CTD locations

738 (Table 2) and of the historical Massifs Coralliens mapped by Le Danois (1948); MCBC:

739 Massif Corallien du Banc de la Chapelle; MBP; Massif Corallien du Sud Ouest de

740 Penmarc'h; MCGV; Massif Corallien de la Grande Vasière. (b). Detail of the Ostrea

741 Spur area with EM1002 bathymetry (contour spacing $25 \mathrm{~m}$ ) and the location of ROV

742 dive B06-02 (white). (c). Detail of the Guilvinec Canyon area with EM1002 bathymetry

743 (contour spacing $25 \mathrm{~m}$ ), with the location of seismic profiles (red) and ROV dives B08-

$744 \quad 02$ and B08-05 (white). 
746 Figure 2: Hydrographic data of the two study areas. (a). Temperature/salinity plot for

747 both CTD casts (Table 2), with indication of the boundary (dashed grey line) between

748 the Eastern North Atlantic Water (ENAW) and the Mediterranean Outflow Water

749 (MOW). The red and blue dashed envelopes refer to the occurrence of cold-water coral

750 (CWC) reefs in respectively the Porcupine Seabight (Dullo et al., 2008) and within the

751 Guilvinec canyon (De Mol et al., accepted). The estimated occurrence envelope of

752 deep-water oysters in the Bay of Biscay is based on the ROV observations (Table 1),

753 plotted on the CTD data of respectively (b) cast "Station 3 cast B" and (c) cast "B0813-

754 CTD-4" in full grey. Here, the black vertical bars indicate the corresponding depth

755 range of ROV observations.

756

757 Figure 3: Seismic profiles Ga080605 (A) and Ga080604 (B), illustrating the seismic

758 stratigraphy and thickness of the sedimentary cover across the Guilvinec Canyon (Fig.

759 1c). Note the asymmetry of canyon morphology and the difference between the

760 sedimentary processes on both flanks. The white dashed lines indicated additional

761 unconformities within the main sequences. These figures have a 10 times vertical

762 exaggeration.

763

764 Figure 4: ROV dive B06-02 track superimposed on the R/V Belgica EM1002

765 bathymetry (contour lines every $50 \mathrm{~m}$ ) with indication of the recognized lithologies,

766 seabed features and the location of the imagery shown in Fig. 5. The black trackline

767 represents a featureless, sandy bioturbated seabed. 
769 Figure 5: Video-derived images of oyster assemblages and facies recognized during

770

771

772

773

774

775

776

777

778

779

780

781

782

783

784

785

786

787

788

789

790

791 dive B06-02 (Fig. 4). Each image bears depth information and orientation. (a) NW-SE straight sand ripples, (b) carbonate knolls with Hexadella sp. sponge, (c) carbonate banks in a series of steps, (d) overhanging carbonate bank with (low-density) oyster community attached below the bank, in association with a dead cold-water coral, (e) close-up of a probably living (high density) deep-water oyster community, (f) steep oyster cliff, note the altitude of the ROV (5.3 $\mathrm{m}$ above sea floor).

Figure 6: ROV dive B08-02 track superimposed on the R/V Belgica EM1002 bathymetry (contour lines every $50 \mathrm{~m}$ ) with indication of the recognized lithologies, seabed features and the location of the stills imagery shown in Fig. 7. The black trackline represents a featureless, silt-sandy bioturbated seabed.

Figure 7: Stills images of oyster assemblages and facies recognized during dive B08-02 (Fig. 6); (a) E-W escarpment ( $\pm 3 \mathrm{~m}$ high) with frequent oyster colonization, (b), S-N oriented escarpment with a mixed solitary oyster and cold-water coral community (Lophelia pertusa, black corals (Parantipathes sp., Stichopathes sp., Trissopathes sp.),

(c) undulatory S-N oriented sand ripples with sparse live solitary Madrepora oculata, (d) leeward side of a W-E outcropping and overhanging rock ( $\pm 1 \mathrm{~m}$ high), colonized by deep-water oysters.

Figure 8: ROV dive B08-05 track superimposed on the R/V Belgica EM1002 bathymetry (contour lines every $50 \mathrm{~m}$ ) with indication of the recognized lithologies, 
792 seabed features and the location of the stills imagery shown in Fig. 9. The black

793 trackline represents a featureless, silty-sandy bioturbated seabed.

794

795 Figure 9: Stills images of oyster assemblages and facies recognized during dive B08-05

796 (Fig. 8); (a) undulatory SSE-NNW oriented sand ripple field and the fish Chimera

797 monstrosa and Helicolenus dactylopterus dactylopterus, (b) overhanging cliff with a

798 thriving mixed oyster and Madrepora oculata colony, (c) distant view of a S-N

799 colonized overhanging cliff, (d) detailed view of the densely packed deep-water oyster

800 community.

801

802 Figure 10: Conceptual sketch of the deep-water oyster environment, based on ROV dive

803 B06-02 on the La Chapelle continental slope. The main oyster communities are located

804 at the gully axis, fed by cascading currents enabling a suitable nutrient supply. The

805 banks upon which the oysters are seated probably are Miocene carbonate banks

806 (calcarenites). 
Click here to download high resolution image
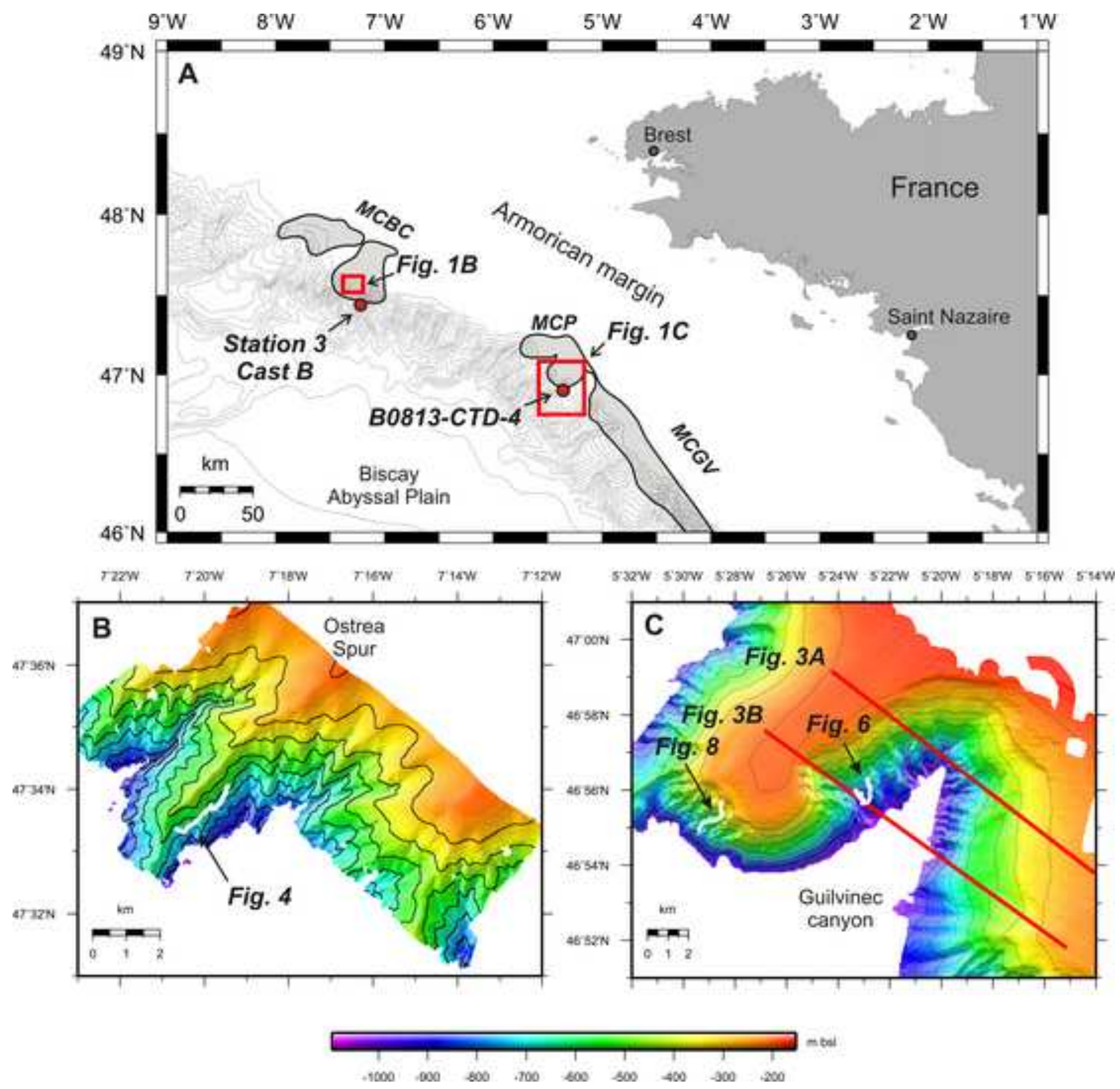

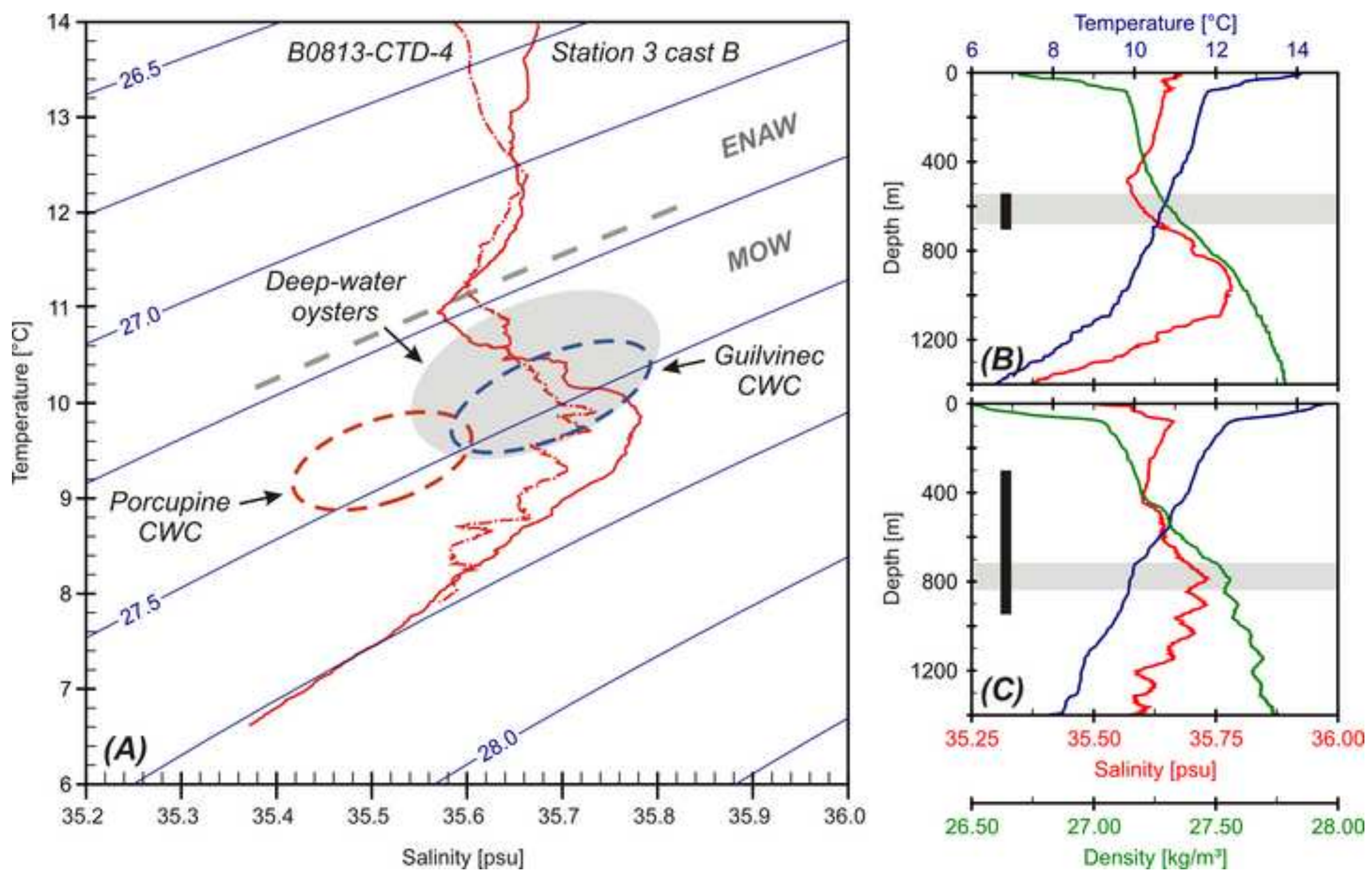

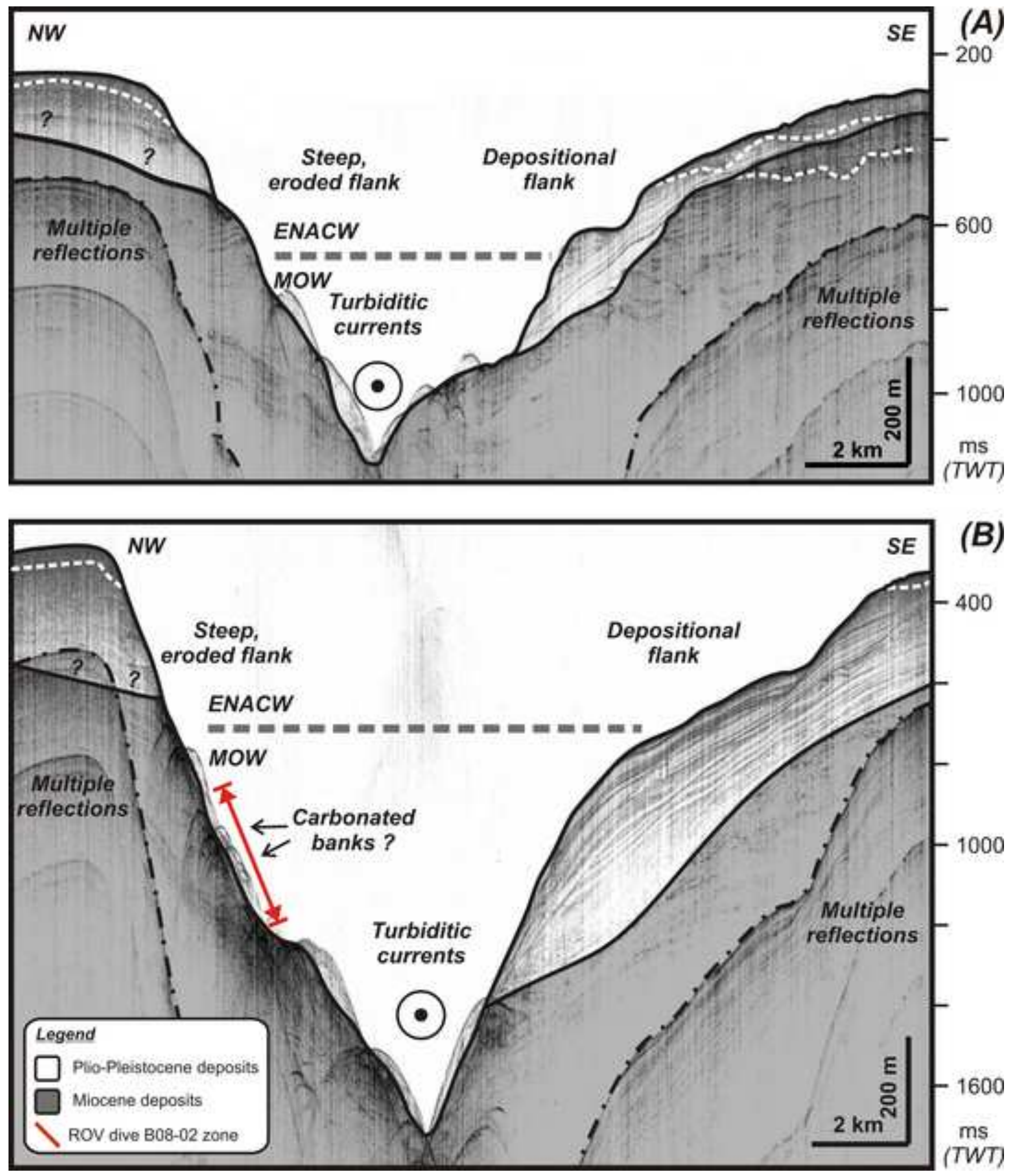


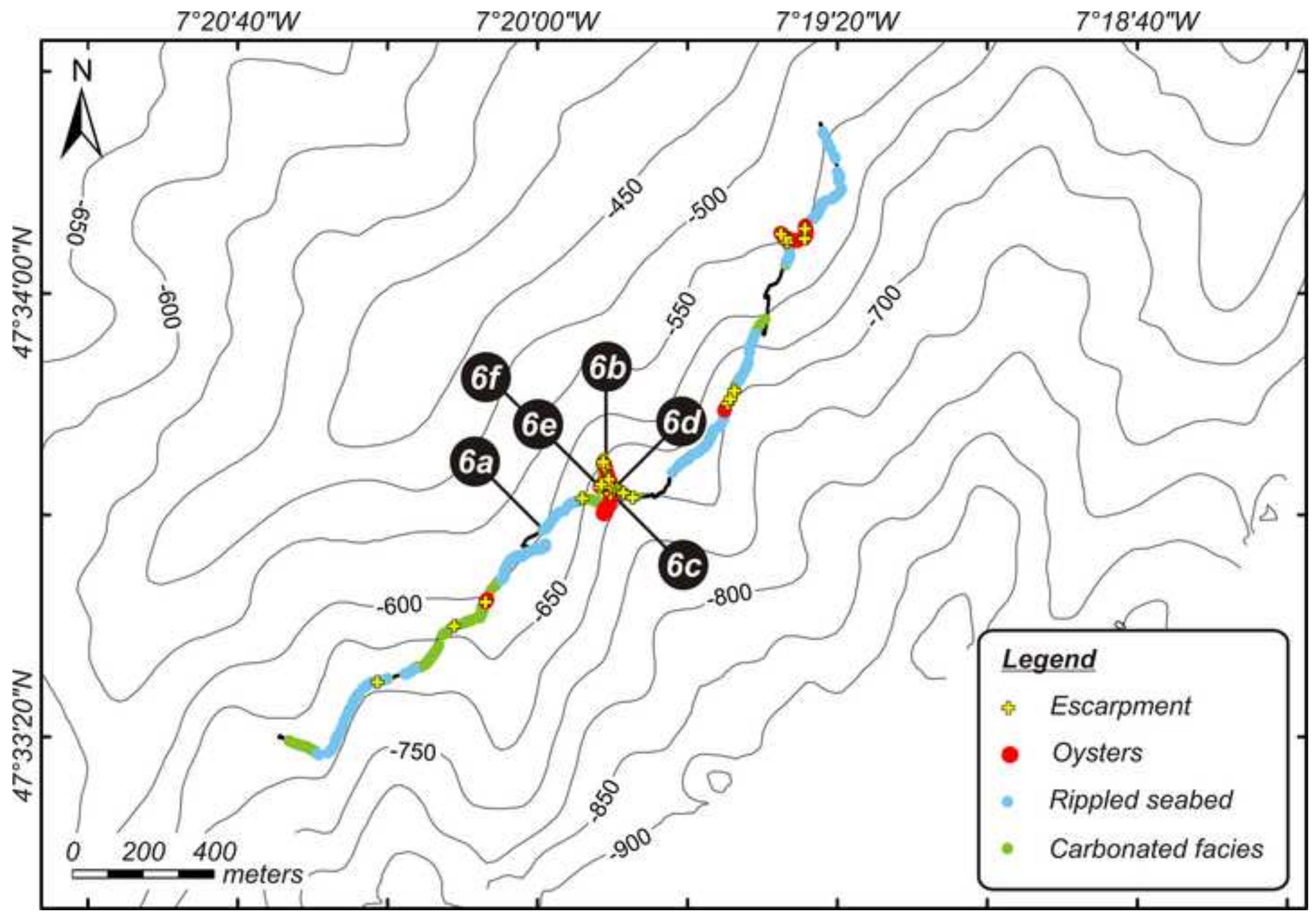


Click here to download high resolution image
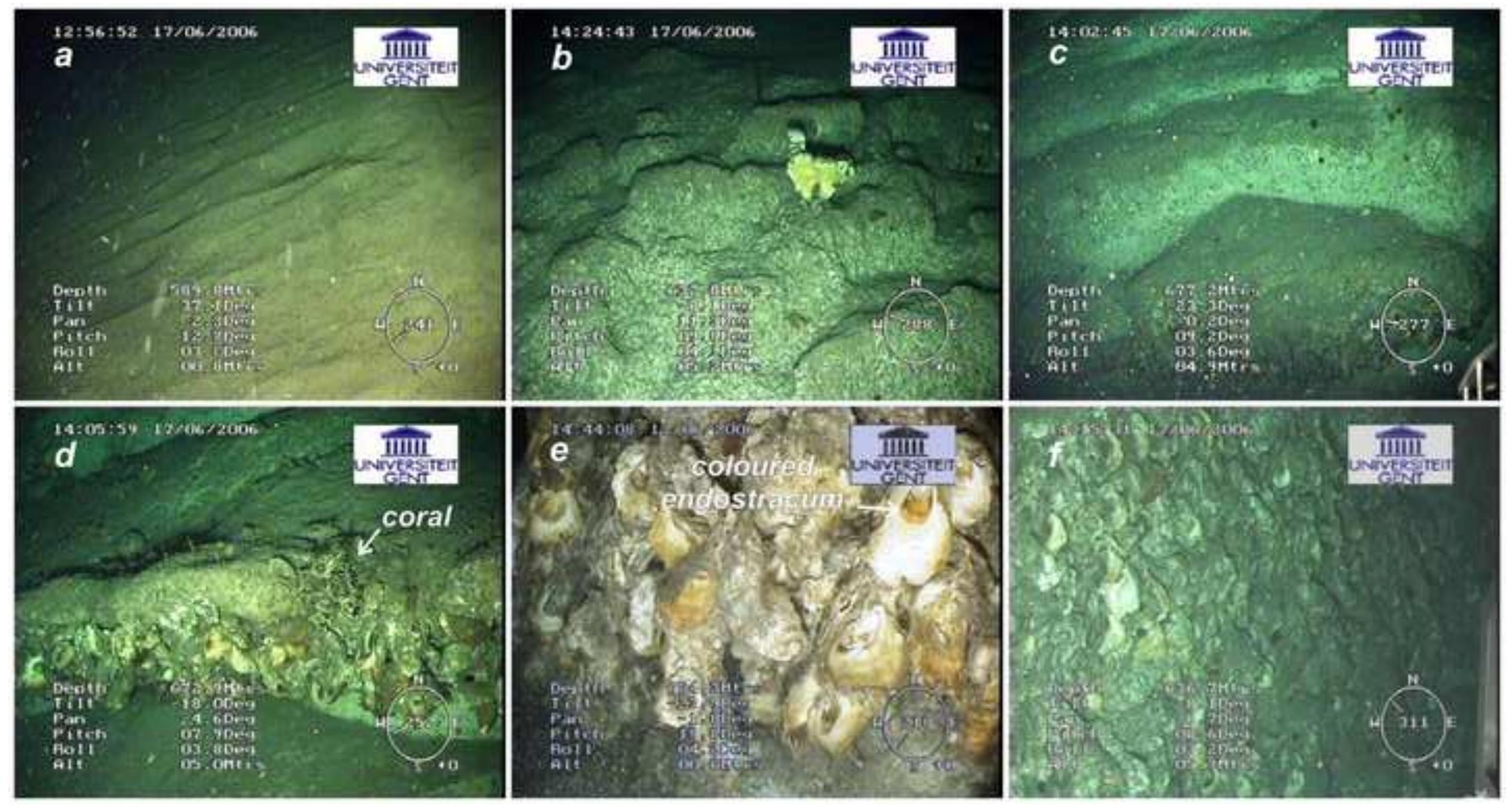


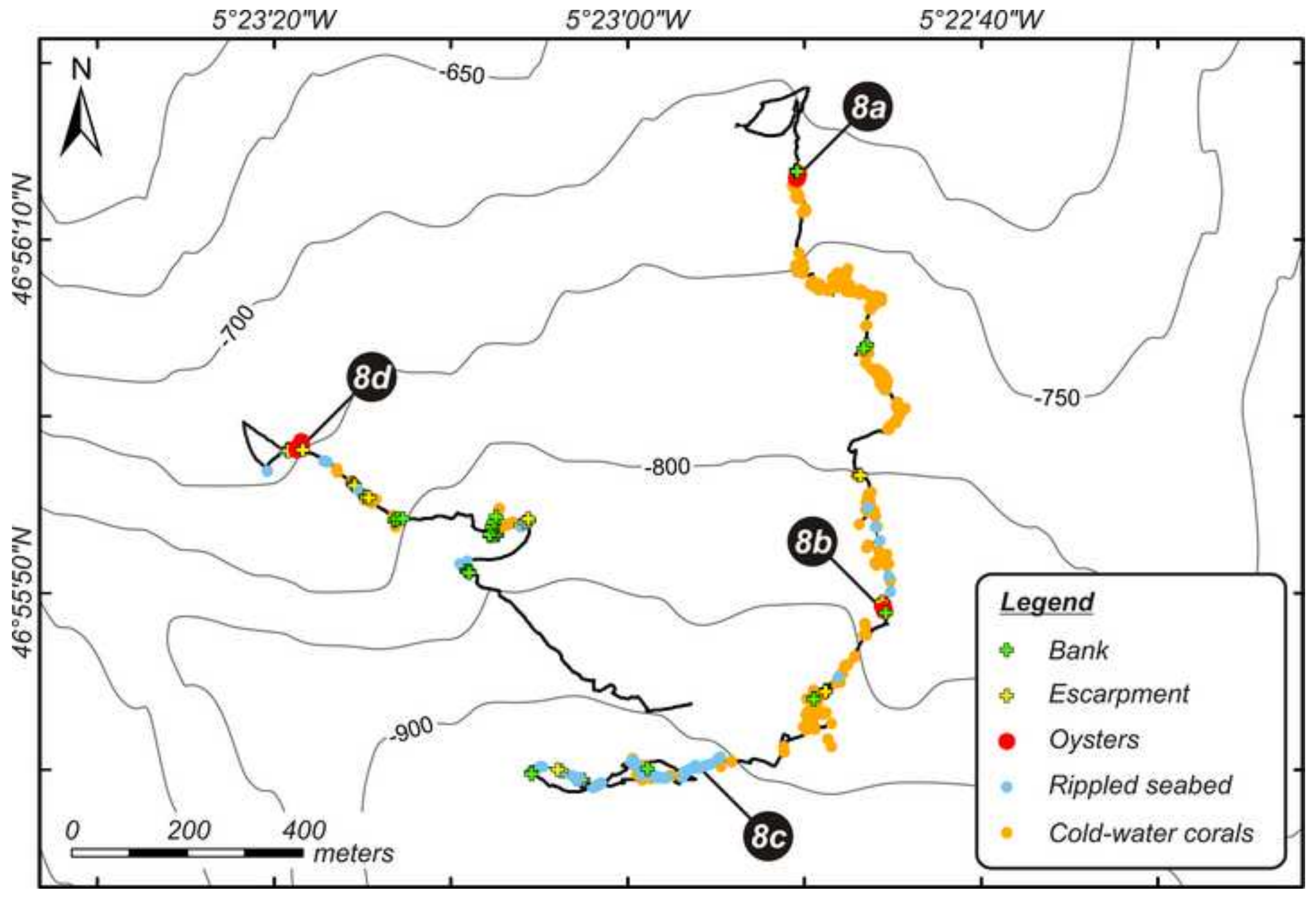


Click here to download high resolution image

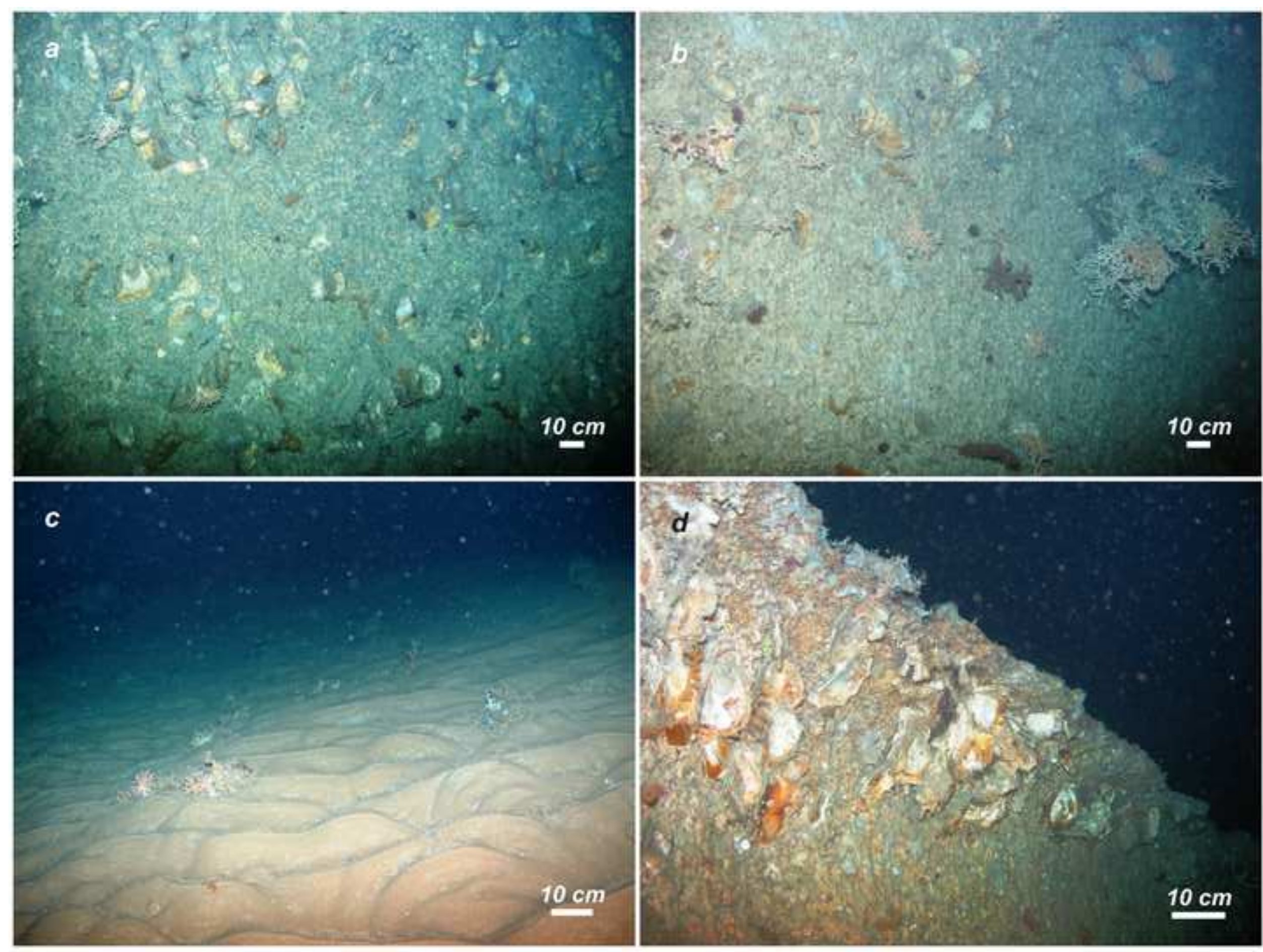




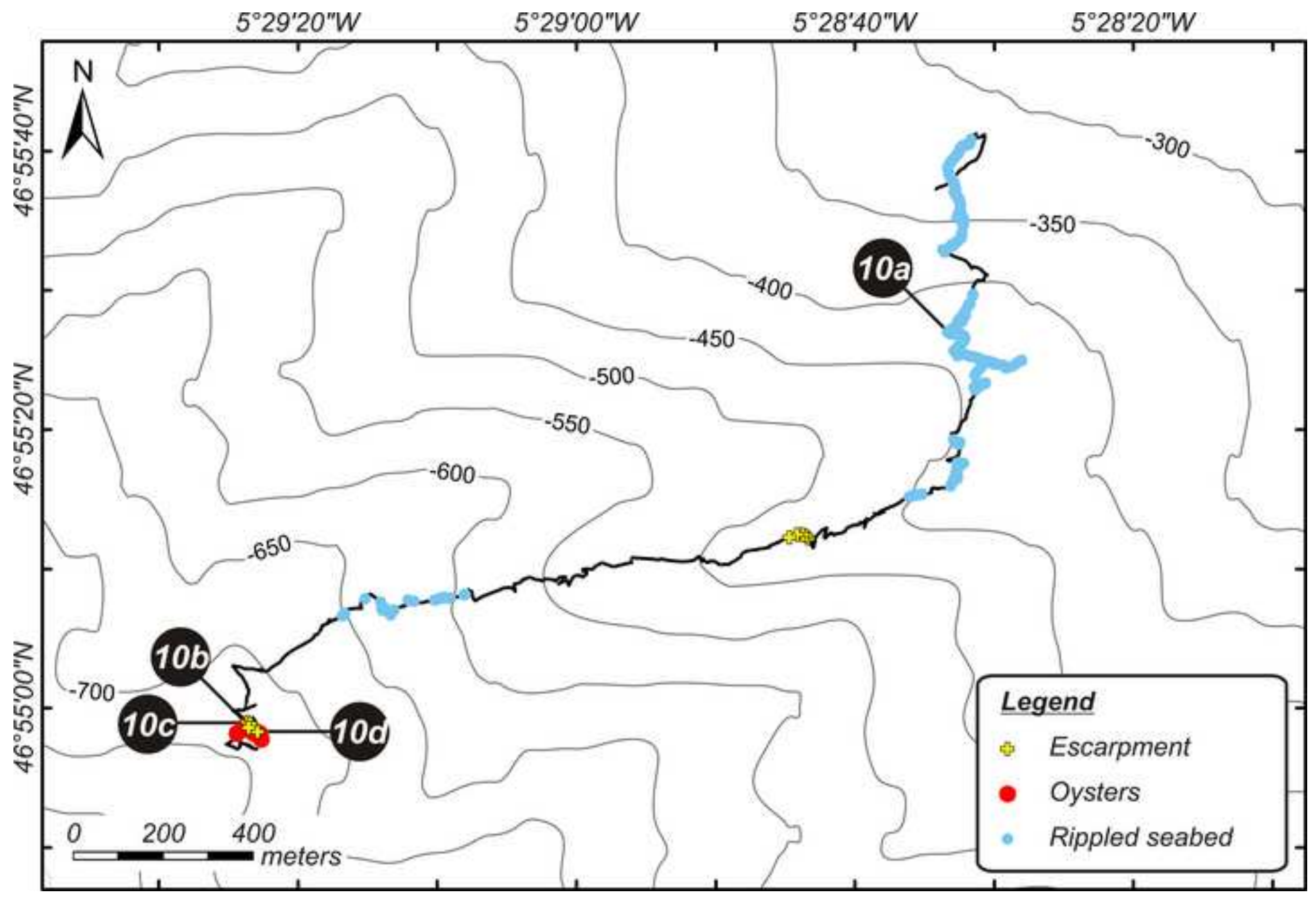


Figure 09
Click here to download high resolution image

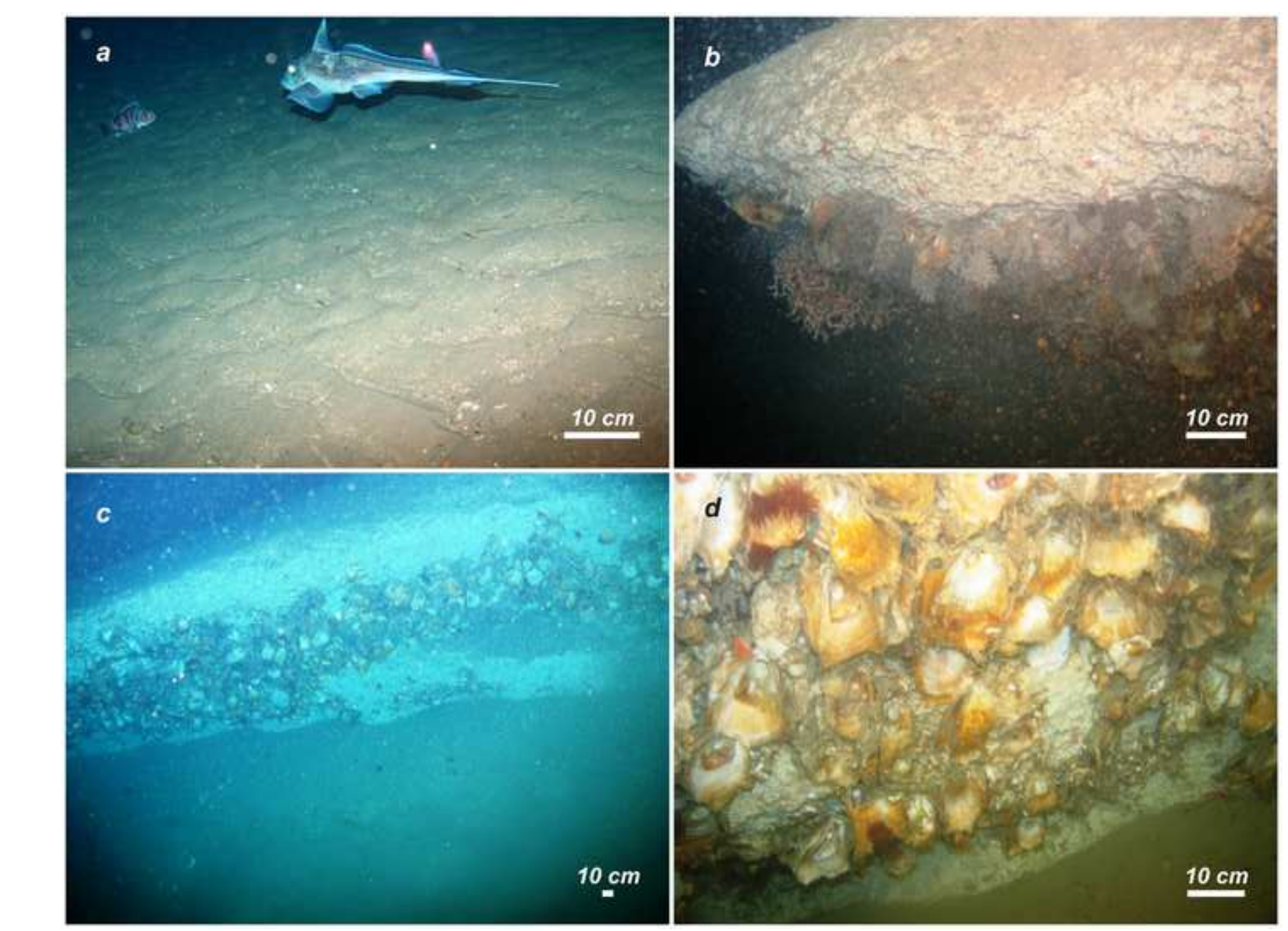

$$
\text { . }
$$
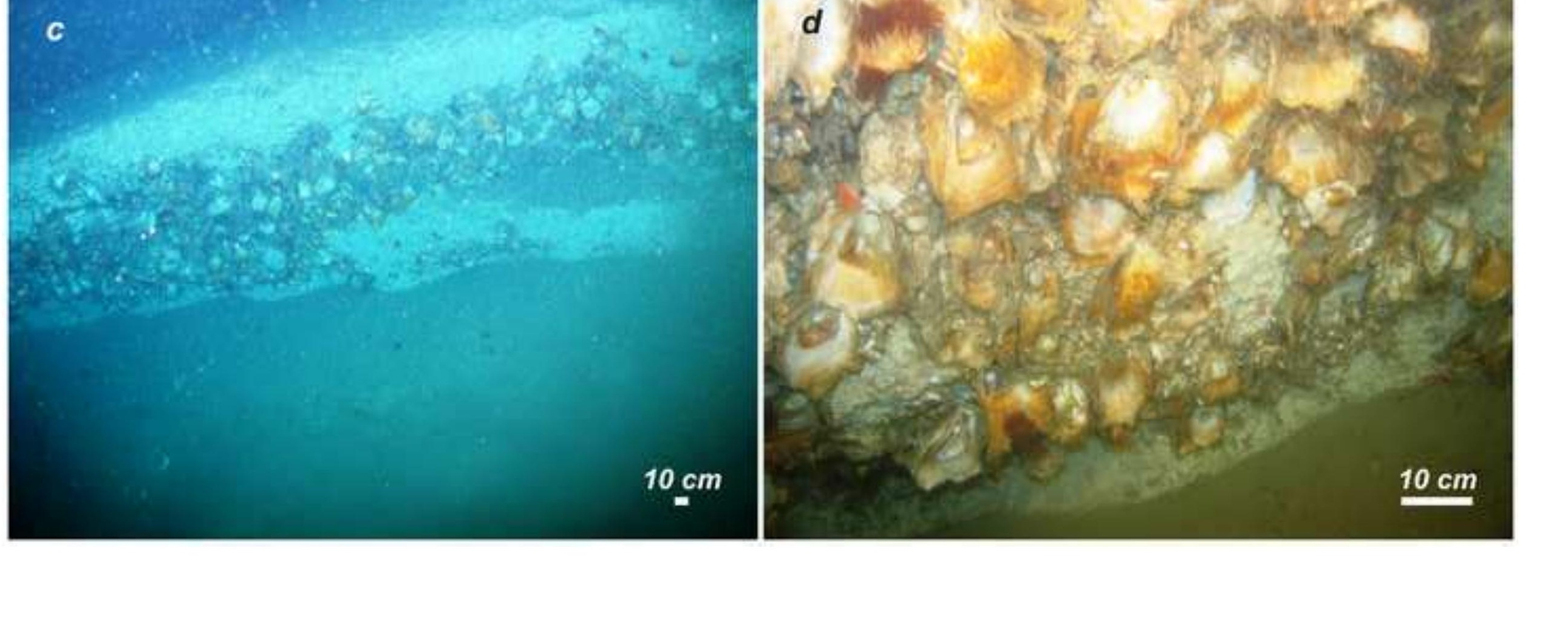


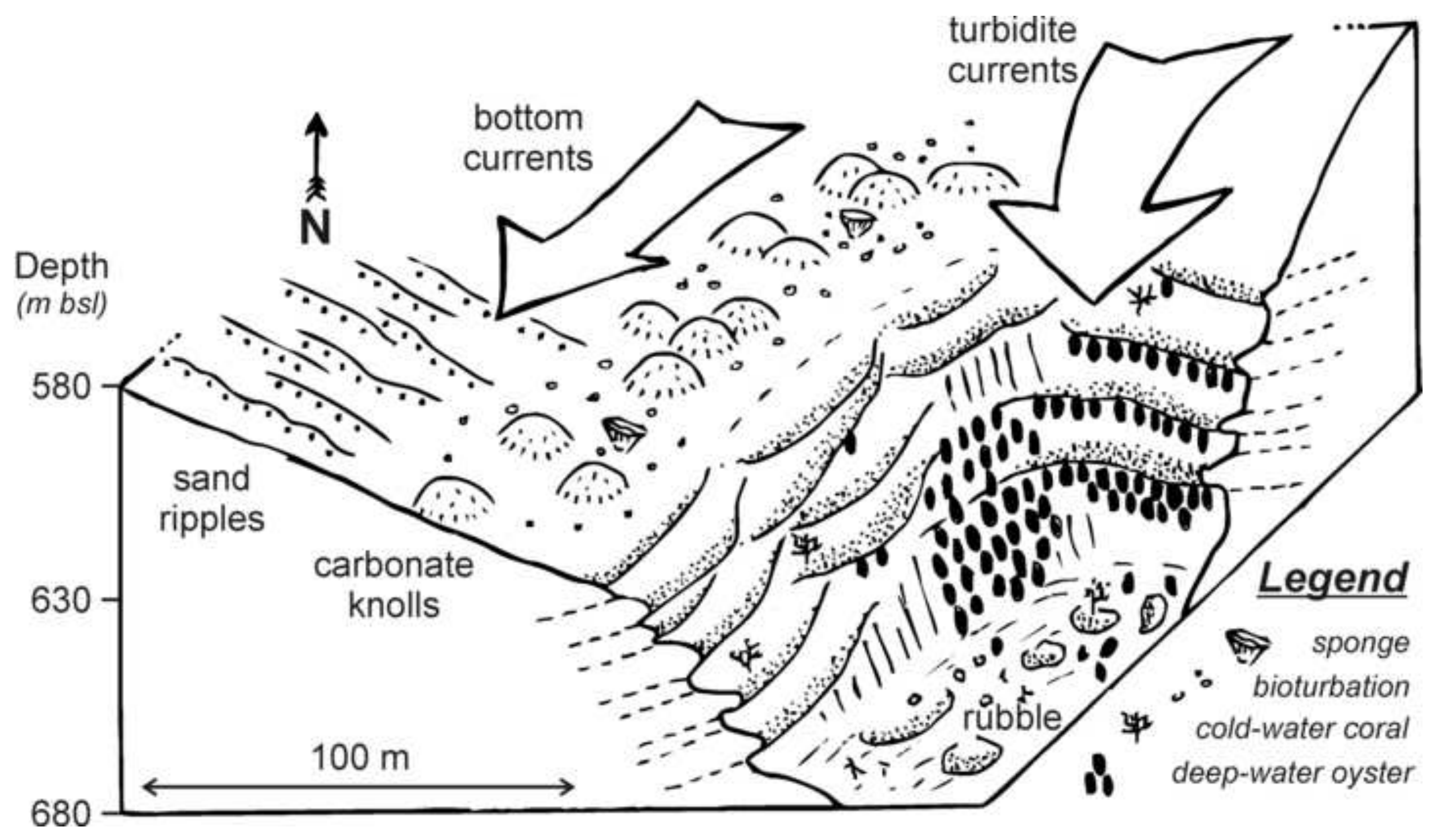

